\section{(2) OPEN ACCESS}

\title{
Genotype-phenotype correlations for pancreatic cancer risk in Dutch melanoma families with pathogenic CDKN2A variants
}

\author{
Kasper A Overbeek (D) , ${ }^{1}$ Mar DM Rodríguez-Girondo, ${ }^{2}$ Anja Wagner, ${ }^{3}$ \\ Nienke van der Stoep, ${ }^{4}$ Peter $\mathrm{C}$ van den Akker, ${ }^{5}$ Jan C Oosterwijk, ${ }^{5}$ Theo A van Os, ${ }^{5}$ \\ Lizet E van der Kolk, ${ }^{6}$ Hans F A Vasen, ${ }^{7}$ Frederik J Hes, ${ }^{4}$ Djuna L Cahen, ${ }^{1}$ \\ Marco J Bruno, ${ }^{1}$ Thomas P Potjer ${ }^{4}$
}

\begin{abstract}
- Additional material is published online only. To view please visit the journal online (http://dx.doi.org/10.1136/ jmedgenet-2019-106562).
\end{abstract}

For numbered affiliations see end of article.

\section{Correspondence to}

Mr Thomas P Potjer, Department of Clinical Genetics, Leiden University Medical Center, Leiden, The Netherlands; T.P.Potjer@lumc.nl

Received 10 September 2019 Revised 27 February 2020 Accepted 20 April 2020 Published Online First 1 June 2020

Check for updates

(c) Author(s) (or their employer(s)) 2021. Re-use permitted under CC BY. Published by BMJ.

To cite: Overbeek KA, Rodríguez-Girondo MDM, Wagner A, et al. J Med Genet 2021:58:264-269.

\begin{abstract}
Background Pathogenic variants in the CDKN2A gene are generally associated with the development of melanoma and pancreatic ductal adenocarcinoma (PDAC), but specific genotype-phenotype correlations might exist and the extent of PDAC risk is not well established for many variants.

Methods Using the Dutch national familial melanoma database, we identified all families with a pathogenic CDKN2A variant and investigated the occurrence of PDAC within these families. We also estimated the standardised incidence ratio and lifetime PDAC risk for carriers of a highly prevalent variant in these families.

Results We identified 172 families in which 649 individuals carried 15 different pathogenic variants. The most prevalent variant was the founder mutation c.225_243del (p16-Leiden, 484 proven carriers). Second most prevalent was c.67G $>$ C (55 proven carriers). PDAC developed in 95 of 163 families (58\%, including 373 of 629 proven carriers) harbouring a variant with an effect on the p16INK4a protein, whereas PDAC did not occur in the 9 families (20 proven carriers) with a variant affecting only p14ARF. In the c.67G >C families, PDAC occurred in 12 of the 251 (5\%) persons at risk. The standardised incidence ratio was 19.1 (95\% Cl 8.3 to 33.6) and the cumulative PDAC incidence at age 75 years (lifetime risk) was 19\% (95\% Cl $7.5 \%$ to $30.1 \%$ ).

Conclusions Our results support the notion that pathogenic CDKN2A variants affecting the p16INK4a protein, including C. $67 \mathrm{G}>\mathrm{C}$, are associated with increased PDAC risk and carriers of such variants should be offered pancreatic cancer surveillance. There is no clinical evidence that impairment of only the p14ARF protein leads to an increased PDAC risk.
\end{abstract}

\section{INTRODUCTION}

The CDKN2A gene (MIM \#600160) is a tumour suppressor gene encoding two distinct proteins using different first exons that are translated through alternative reading frames. The $\mathrm{p} 16 \mathrm{INK} 4 \mathrm{a}$ protein is coded by exons $1 \alpha, 2$ and 3, while the p14ARF protein is coded by $1 \beta$ and a part of exon $2 .{ }^{1}$ Thus, a germline mutation (henceforth referred to as pathogenic variant) can affect one or both of these proteins, depending on its location in the CDKN2A gene. Although both proteins act as tumour suppressors, they do so through different pathways. The p16-retinoblastoma pathway controls cell cycle G1 phase exit, whereas the p14ARF-p53 pathway induces cell cycle arrest or apoptosis. ${ }^{2}$ These properties suggest that $C D K N 2 A$ variants may display specific genotype-phenotype correlations with risk of malignancy.

The most important malignancy associated with pathogenic variants in the CDKN2A gene is cutaneous melanoma, for which carriers have a lifetime risk of $70 \% .^{3}$ Pathogenic variants are found in up to $40 \%$ of high-density melanoma families, and $C D K N 2 A$ is therefore the major high-risk susceptibility gene for hereditary cutaneous melanoma. ${ }^{14}$ The second most frequent tumour is pancreatic ductal adenocarcinoma (PDAC), ${ }^{5-9}$ for which the lifetime risk is up to $20 \% .^{9-12}$ This level of risk is among the highest for the known PDAC susceptibility genes, ${ }^{12}$ and pathogenic variants in the CDKN2A gene are even found in familial pancreatic cancer families that do not have cases of melanoma. ${ }^{14-16}$ Due to this high PDAC risk, carriers are eligible to be included in a pancreatic cancer surveillance programme. ${ }^{17}$

In melanoma families, pathogenic variants in the CDKN2A gene are found across the entire coding region and therefore may affect either p16INK4a, p14ARF or both. ${ }^{3618}$ However, for the risk of PDAC, genotype-phenotype correlations for specific CDKN2A variants have been proposed, based on the observation that PDAC is only found in relation to variants affecting $\mathrm{p} 16 \mathrm{INK} 4 \mathrm{~A}$ (with or without an effect on p14ARF). ${ }^{6719}$ PDAC-associated variants include the founder mutation c.225_243del in exon 2, also known as p16-Leiden, the most commonly found pathogenic variant in the Netherlands, ${ }^{20} 21$ which conveys an estimated lifetime risk for PDAC of $15 \%-20 \% .^{8}{ }^{10}$ Genetic testing of Dutch melanoma families also regularly identifies pathogenic variants other than $\mathrm{p} 16$-Leiden, ${ }^{22}$ for which the exact PDAC risk is often uncertain. ${ }^{19}$ The uncertainty surrounding PDAC risk in non-p16-Leiden carriers precludes offers of surveillance within a pancreatic cancer surveillance research programme, as these programmes are reserved for individuals with a proven increased lifetime risk. ${ }^{17}$ The aim of this study was to further explore the possible 
genotype-phenotype correlation between pathogenic CDKN2A variants and PDAC risk. To this end, we assessed the occurrence of PDAC in Dutch melanoma families with a (likely) pathogenic $C D K N 2 A$ variant. In addition, we determined the lifetime PDAC risk for the second most prevalent pathogenic variant in the Netherlands using detailed pedigree information.

\section{METHODS}

\section{Study design and data collection}

Data for this study were derived from the previously described Dutch national database for familial melanoma. ${ }^{22}$ In this database, clinical information is stored on all melanoma families that have been tested for CDKN2A pathogenic variants at the Laboratory for Diagnostic Genome Analysis of the department of Clinical Genetics at Leiden University Medical Centre. This laboratory has been the primary sequencing facility for CDKN2A in the Netherlands since 1998, and performs sequencing for all clinical genetics departments in the Netherlands. According to Dutch referral guidelines, CDKN2A sequencing is indicated if the family meets one of the following criteria: (1) Two first-degree relatives with melanoma. (2) Two first-degree or second-degree relatives with melanoma and one first-degree or second-degree relative with PDAC. (3) Three or more primary melanomas in one individual. (4) An individual with melanoma under 18 years of age. (5) An individual with a history of both melanoma and PDAC.

Using this national database, we selected all melanoma families in which a pathogenic or likely pathogenic germline CDKN2A variant (class 4 or 5 variant) ${ }^{23}$ was identified during the period 1998-2015, regardless of the occurrence of PDAC in the family. Classification of these variants was based on previously reported co-segregation with disease and/or strong evidence of impaired protein function. Families with a variant of uncertain significance (class 3$)^{23}$ were also included when the variant was shown through linkage analysis to be located on a pathogenic CDKN2A haplotype. The linkage criteria are based on haplotype mapping analysis data using eight simple polymorph tandem repeat microsatellite markers (region D9S1878-D9S162) encompassing the CDKN2A genomic region and neighbouring genes (9p13.3-9p22.1). Previous studies have shown that it is reliable to use simple tandem repeat polymorphism markers in this region to identify a common haplotype in different families. ${ }^{24} 25$ When variant carriers from a single large family ( $>8$ meioses) or from different families carried a common haplotype for these markers per investigated variant (and healthy control family members and other control samples did not), the haplotype was classified as pathogenic.

Pedigrees were reviewed and updated for the occurrence of PDAC in any family member up to August 2018. Since the positive predictive value of self-reported family history for PDAC has been reported to exceed $75 \%,{ }^{26}$ we included information on all reported PDAC diagnoses. For each individual family member, mutation status, history of any type of cancer, age at cancer diagnosis, age at last follow-up, and age and cause of death (if applicable) were updated by the referring clinical genetics department.

\section{Statistical analysis}

Descriptive statistics were used to describe the prevalence of the different pathogenic CDKN2A variants and of PDAC within these families. For the second most prevalent variant (c. $67 \mathrm{G}>\mathrm{C}$, p.(Gly23Arg)) we assessed the cumulative lifetime PDAC risk using detailed pedigree information. First, we excluded PDAC cases that were the index patient of their family, to prevent overestimation of risk as a result of ascertainment bias. We also excluded proven non-carriers, and all untested second-degree or higher-degree family members of a proven carrier, to prevent the effect of a likely reporting bias. Included in the analysis were proven carriers, obligate carriers, and untested first-degree family members of a proven or obligate carrier. Second, a standardised incidence ratio (SIR) was calculated, as the ratio of observed to expected cancers. The expected number of cancers was calculated based on the sum of all individual cumulative hazards derived from sex and age group-specific incidence rates for PDAC in the general Dutch population. ${ }^{27}$ Third, we estimated cumulative lifetime risk, defined as cumulative PDAC incidence by 75 years of age, using the Kaplan-Meier method. Mutation probabilities based on kinship coefficients were used as analytical weights in the Kaplan-Meier analysis, to avoid possible testing bias and increase efficiency. We calculated 95\% CIs for both the SIR and the lifetime risk using bootstrapping at the family level (1000 repetitions).

\section{RESULTS}

\section{Pathogenic CDKN2A variants}

Between 1998 and 2015, a total of 15 different (likely) pathogenic CDKN2A variants was found in 172 CDKN2A-mutated melanoma families that included a total of 649 proven variant carriers (table 1). Seven variants affected both the p16INK4a and p14ARF proteins (143 families, 543 proven carriers), six variants solely the p16INK4a protein (20 families, 86 proven carriers), and two variants solely the p14ARF protein ( 9 families, 20 proven carriers). The p16-Leiden variant (c.225_243del, p.(Ala76Cysfs*64)) was found in the majority of families (131/172 families, $76 \%)$. The frequencies of the 15 variants are presented in figure 1.

\section{Pancreatic cancer occurrence}

PDAC occurred in 95 families (55\%, 373 proven carriers, table 1 and figure 1). Regarding variants affecting both proteins, 59\% of the families with such a variant included cases of PDAC and these families accounted for $59 \%$ of the proven carriers of these variants. For variants affecting solely p16INK4a, PDAC was observed in $55 \%$ of the families, accounting for $64 \%$ of the proven carriers. When excluding the two most common variants (c.67G $>$ C and c.225_243del), PDAC was observed in 2/12 $(17 \%)$ families with a variant affecting both proteins, and in $5 / 11(45 \%)$ families with a variant affecting solely p16INK4a. Combining all variants with an effect on p16INK4a, regardless of the effect on p14ARF, PDAC occurred in 95/163 (58\%) families that included 373/629 (59\%) proven carriers. By contrast, PDAC was not observed in the nine families (20 proven carriers) with a variant solely affecting the p14ARF protein.

\section{CDKN2A c.67G >C variant and pancreatic cancer risk}

The c.67G $>$ C, p.(Gly23Arg) variant was found in nine families and is therefore the second most prevalent pathogenic CDKN2A variant found in Dutch melanoma families (table 1 and figure 1 ). Together, these families comprised 251 at-risk family members (84 proven and obligate carriers, 90 individuals with an a priori $50 \%$ chance of carriership and 77 with an a priori $25 \%$ chance; table 2). During a total follow-up of 10414 person-years, PDAC developed in 12 individuals (9 were carriers, including 2 PDAC index cases; 2 had a 50\% chance of carriership; 1 a 25\% chance). PDAC did not develop in the 52 proven non-carriers.

After excluding the two PDAC index cases and the family members with a $25 \%$ chance of carriership, the ratio of observed/ 


\begin{tabular}{|c|c|c|c|c|c|c|c|c|}
\hline Variant location & CDKN2A nucleotide change* & $\begin{array}{l}\text { CDKN2A/p16INK4a } \\
\text { amino acid change }\end{array}$ & $\begin{array}{l}\text { CDKN2A/p14ARF } \\
\text { amino acid change }\end{array}$ & $\begin{array}{l}\text { Total no. of families } \\
\text { (no. of proven carriers) }\end{array}$ & $\begin{array}{l}\text { No. of families with PDAC } \\
\text { (no. of proven carriers in } \\
\text { these families) }\end{array}$ & $\begin{array}{l}\text { No. of } \\
\text { PDAC cases } \\
\text { (no. of validatedt } \\
\text { cases) }\end{array}$ & $\begin{array}{l}\text { No. of proven carriers } \\
\text { with PDAC } \\
\text { + no. of obligate } \\
\text { carriers with PDAC }\end{array}$ & $\begin{array}{l}\text { PDAC occurrence in } \\
\text { literature }\end{array}$ \\
\hline Exon $1 \beta$ & c. $193 \mathrm{G}>\mathrm{C}$ & None & p.(Gly65Arg) & $4(8)$ & $0(-)$ & $0(-)$ & $0+0$ & No \\
\hline Exon $1 \beta$ & c. $193+1 G>A$ & None & p.? (splicing) & $5(12)$ & $0(-)$ & $0(-)$ & $0+0$ & No \\
\hline Exon $1 \alpha$ & c. $-34 \mathrm{G}>\mathrm{T}$ & p.? & None & $4(8)$ & $0(-)$ & $0(-)$ & $0+0$ & Yes $^{67151937}$ \\
\hline Exon $1 \alpha$ & c. $47 \mathrm{~T}>\mathrm{G}$ & p.(Leu16Arg) & None & $3(9)$ & $2(5)$ & $2(0)$ & $0+1$ & Yes $^{1519}$ \\
\hline Exon $1 \alpha$ & c. $67 \mathrm{G}>\mathrm{C}$ & p.(Gly23Arg) & None & $9(55)$ & $6(39)$ & $12(5)$ & $5+4$ & No \\
\hline Exon $1 \alpha$ & c. $71 \mathrm{G}>\mathrm{C}$ & p.(Arg24Pro) & None & $2(3)$ & $2(3)$ & $2(2)$ & $2+0$ & Yes $^{67151937}$ \\
\hline Exon $1 \alpha$ & c.131-132insAA & p. $\left(\operatorname{Tyr} 44^{*}\right)$ & None & $1(3)$ & $0(-)$ & $0(-)$ & $0+0$ & Yes $^{1519}$ \\
\hline Exon $1 \alpha$ & c. $143 \mathrm{C}>\mathrm{A}$ & p.(Pro48GIn) & None & $1(8)$ & $1(8)$ & $3(1)$ & $1+1$ & Variant not reported \\
\hline Exon 2 & c. $151-2 A>G$ & p.? (splicing) & p.? (splicing) & $1(12)$ & $1(12)$ & $1(0)$ & $0+0$ & Variant not reported \\
\hline Exon 2 & c. $159 \mathrm{G}>\mathrm{A}$ & p.(Met53lle) & p.(Asp68Asn) & $2(5)$ & $1(4)$ & $1(1)$ & $0+0$ & Yes ${ }^{1519}$ \\
\hline Exon 2 & $c .203 C>T$ & p.(Ala68Val) & p.(Arg82Arg) & $2(7)$ & $0(-)$ & $0(-)$ & $0+0$ & $Y_{e s}^{36}$ \\
\hline Exon 2 & c.225_243del & p.(Ala76Cysfs*64) & p. (Arg90Valfs*76) & $131(484)$ & $82(302)$ & NA & NA & Yes ${ }^{6-8} 1015161937$ \\
\hline Exon 2 & $c .301 \mathrm{G}>\mathrm{T}$ & p.(Gly101Trp) & p.(Arg115Leu) & $2(2)$ & 0 & $0(-)$ & $0+0$ & $Y_{e s}^{6714151937}$ \\
\hline Exon 2 & c. $352 \mathrm{G}>\mathrm{A}$ & p.(Ala118Thr) & p.(Gly132Asp) & $4(31)$ & 0 & $0(-)$ & $0+0$ & Variant not reported \\
\hline Exon $1+2+3$ & $\begin{array}{l}\text { Deletion } 155 \mathrm{~kb} \text { of CDKN2A, } \\
\text { CDKN2B and partially MTAP }\end{array}$ & $\begin{array}{l}\text { p.? } \\
\text { (whole gene deletion) }\end{array}$ & $\begin{array}{l}\text { p.? } \\
\text { (whole gene deletion) }\end{array}$ & $1(2)$ & 0 & $0(-)$ & $0+0$ & Variant not reported \\
\hline
\end{tabular}

The variants c.143C >A and c.203C >T are located on a pathogenic haplotype.
*RefSeq NM_000077.4 isoform p16INK4a, RefSeq NM_058195.3 isoform p14ARF (for exon 1B).

*RefSeq NM_000077.4 isoform p16INK4a, RefSeq N
tThrough medical records and/or pathology reports.

CDKN2A, cyclin-dependent kinase inhibitor $2 A ; N A$, not analysed; PDAC, pancreatic ductal adenocarcinoma.

expected cases was 9/0.47, resulting in a SIR of 19.1 (95\% CI 8.3 to 33.6). The cumulative PDAC incidence for carriers of the c. $67 \mathrm{G}>\mathrm{C}$, p.(Gly23Arg) variant is shown in figure 2 . At age 75 years, the cumulative PDAC incidence (lifetime risk) was 19\% (95\% CI $7.5 \%$ to $30.1 \%$ ).

\section{DISCUSSION}

The precise relationship between the CDKN2A gene and PDAC is unclear and an association has only been confirmed for a subset of pathogenic variants. ${ }^{19}$ In order to properly counsel carriers and to determine whether they are eligible for pancreatic

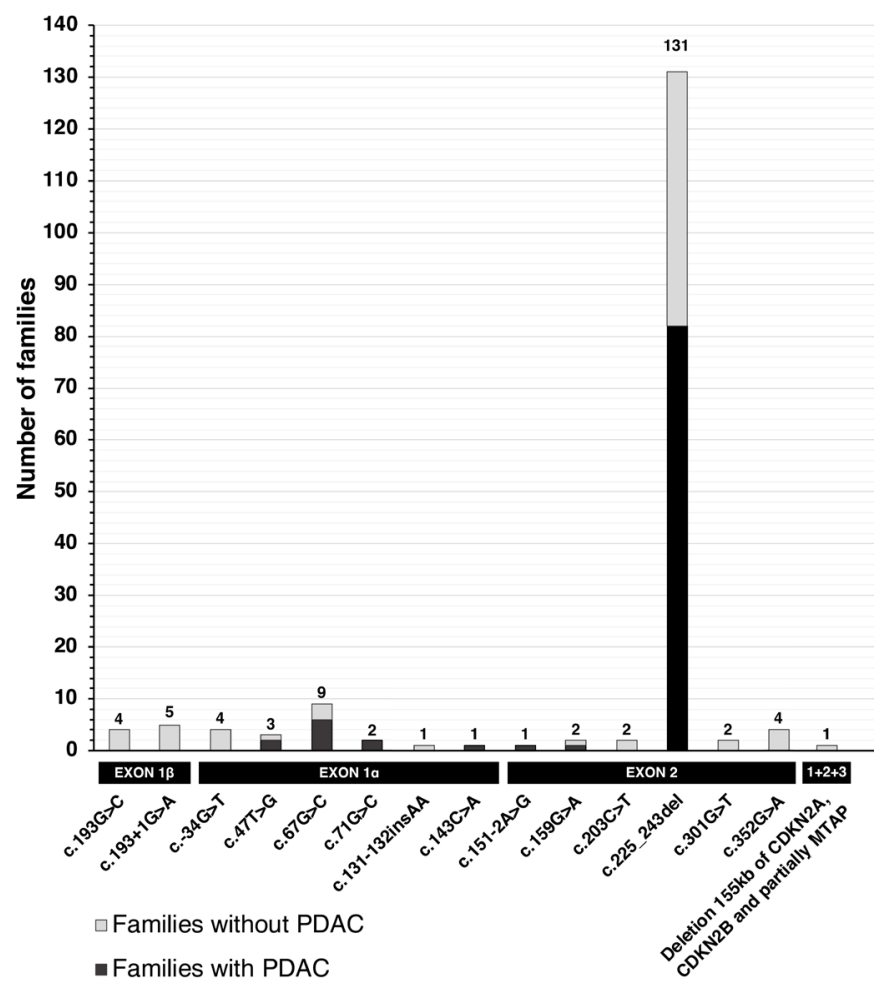

Figure 1 Visualisation of variant frequencies and pancreatic cancer occurrence. PDAC, pancreatic ductal adenocarcinoma. cancer surveillance, a better understanding of possible genotypephenotype correlations is needed. In this study, we investigated PDAC occurrence in a Dutch nationwide cohort of melanoma families with a (likely) pathogenic CDKN2A germline variant, and estimated the lifetime risk associated with the variant c.67G $>C$, p.(Gly23Arg). Of the 15 different variants, the majority (87\%) affected the p16INK4a protein and PDAC occurred in 58\% of families harbouring these variants. By contrast, we observed no PDAC in carriers (or their family members) of the two variants (both in exon 1 $\beta$ ) that solely affected the p14ARF protein (9 families, 20 carriers). This outcome supports the findings of earlier studies, which are summarised in online supplementary tables 1 and 2. To date, a total of 35 families with exon $1 \beta$ variants (including the 9 families in our current study) have been reported worldwide, and PDAC has not been reported in any of them (see online supplementary table 1 ). A recent meta-analysis also failed to find an association between PDAC and pathogenic variants in exon $1 \beta .{ }^{19}$ In our cohort, all variants in exon 2 impaired both proteins, but other studies have described patients with melanoma and families with exon 2 variants altering only one of the two proteins. These studies have reported PDAC occurrence for exon 2 variants affecting only p16INK4a, ${ }^{6}$ but there are no such reports for exon 2 variants solely altering p14ARF (see online supplementary table 2). Of note, in a study by Kannengiesser et al, ${ }^{28}$ PDAC was reported in two out of four melanoma families with the c.339G $>$ A variant that solely affects p14ARF, but as this variant is co-occurring in these families with a second variant that does alter p16INK4A (c.340C >T), they cannot be considered as sole p14ARF-families. Thus, although variants affecting only p14ARF have been described in a small number of families, these earlier observations together with our own findings strongly suggest that impairment of only the p14ARF protein (and therefore the p14ARF-p53 pathway) is not associated with an increased PDAC risk. Of the individual variants in our cohort, the most prevalent was the p16-Leiden variant (c.225_243del, p.(Ala76Cysfs*64)), which was present in the majority (76\%) of families, in many of which (63\%) PDAC occurred. This is unsurprising, as earlier studies have described the high prevalence of this variant in the Netherlands and its strong association with PDAC. ${ }^{810}$ Yet, other pathogenic variants 
Table 2 Details of the families in which the c.67G >C, p.(Gly23Arg) variant was found

\begin{tabular}{|c|c|c|c|c|c|c|}
\hline Family number & $\begin{array}{l}\text { Total number of family } \\
\text { members at risk* }\end{array}$ & Carrierst & $\begin{array}{l}50 \% \text { chance of } \\
\text { carriership }\end{array}$ & $\begin{array}{l}25 \% \text { chance of } \\
\text { carriership }\end{array}$ & $\begin{array}{l}\text { Proven non- } \\
\text { carriers }\end{array}$ & $\begin{array}{l}\text { No. of PDAC cases in carrierst and } \\
\text { possible carriers } \\
\text { (of which validated } \ddagger \text { ) }\end{array}$ \\
\hline 1 & 11 & 7 & 4 & 0 & 3 & $0(-)$ \\
\hline 2 & 56 & 9 & 17 & 30 & 5 & $3(1)$ \\
\hline 3 & 44 & 11 & 19 & 14 & 7 & $1(1)$ \\
\hline 4 & 26 & 9 & 7 & 10 & 6 & $0(-)$ \\
\hline 5 & 8 & 6 & 2 & 0 & 9 & $4(2)$ \\
\hline 6 & 53 & 24 & 21 & 8 & 16 & $2(0)$ \\
\hline 7 & 19 & 6 & 7 & 6 & 0 & $1(1)$ \\
\hline 8 & 14 & 9 & 5 & 0 & 5 & $0(-)$ \\
\hline 9 & 20 & 3 & 8 & 9 & 1 & $1(0)$ \\
\hline Total & 251 & 84 & 90 & 77 & 52 & 12 \\
\hline
\end{tabular}

*Proven non-carriers excluded.

tIncludes proven and obligate carriers.

¥Through medical records and/or pathology reports.

PDAC, pancreatic ductal adenocarcinoma.

were also found regularly (in 24\% of families), the most prevalent was c.67G >C, p.(Gly23Arg). Single families harbouring this variant ${ }^{29} 30$ or other variants within the same $\operatorname{codon}^{29-35}$ have been previously described, mainly in the context of melanoma risk. Of these studies only one also reported on PDAC occurrence, describing a single case in a second-degree relative of a c. $67 \mathrm{G}>\mathrm{A}$, p.(Gly23Ser) variant carrier. ${ }^{34}$ Based on our larger set of nine families, we estimated the lifetime PDAC risk associated with this specific variant to be approximately equivalent to that of the p16-Leiden variant (estimated at 15\%-20\%). ${ }^{8} 10$

Of the remaining 13 variants, 10 have been found in families in other countries, ${ }^{71936}$ but 3 have not been previously described in literature. These were c.143C $>\mathrm{A}$ (located on a pathogenic haplotype), c.151-2A $>\mathrm{G}$ and a deletion of $155 \mathrm{~kb}$ spanning CDKN2A, CDKN2B and a part of MTAP. Two of these variants (c.143C $>$ A and c.151-2A $>$ G) were identified in families with one or more occurrences of PDAC. Since the majority of variants affecting p16INK4a in our study were identified in melanoma families with one or more occurrences of PDAC, and most other variants affecting $\mathrm{p} 16 \mathrm{INK} 4 \mathrm{a}$ have been associated with a positive family history for PDAC in previous studies (table 1), our results contribute to a growing body of evidence that suggests that all pathogenic variants affecting the p16INK4a protein convey an

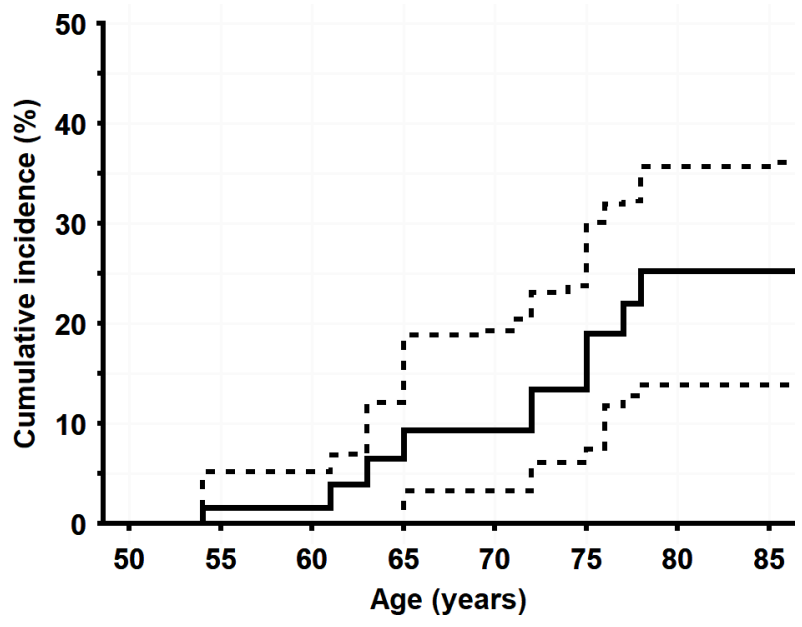

Figure 2 Cumulative pancreatic cancer incidence for C.67G $>$ C, p.(Gly23Arg) carriers, with 95\% Cls shown as dashed lines. increased PDAC risk. This trend is further supported by the risk estimates for the two most prevalent variants in the Netherlands, both of which affect p16INK4a and exceed the 5\% threshold defined by the international cancer of the pancreas surveillance consortium. ${ }^{17}$ Although we consider it likely that most other pathogenic variants affecting p16INK4a will exceed the 5\% lifetime risk threshold for PDAC surveillance as well, we could not specifically investigate this for every single variant in our cohort due to their low prevalence. We do acknowledge that somewhat lower frequencies of PDAC have previously been reported in families harbouring variants in specific domains of the CDKN $2 A$ gene, that is, the ankyrin repeats 1 and 2 (corresponding to codons $11-71$ of the p16INK4a transcript), ${ }^{6737}$ but our data do not support this possible genotype-phenotype correlation between variants in specific ankyrin repeats and PDAC risk since the c.67G $>$ C, p. (Gly23Arg) variant lies within the ankyrin repeat 1 and has shown a particular strong association with PDAC risk. Therefore, based on existing literature and this study, all carriers of pathogenic CDKN2A variants affecting p16INK4a should be considered candidates for PDAC surveillance, until convincing evidence to the contrary emerges. Conversely, available evidence does not support an increased PDAC risk in carriers of variants solely affecting p14ARF, and carriers of these variants should, therefore, not be offered surveillance at this time. Our study had several strengths. The centralised Dutch database for families harbouring (likely) pathogenic CDKN2A variants allowed us to examine the complete spectrum of variants and the occurrence of PDAC on a national level. This facilitated estimation of the lifetime PDAC risk for the second most prevalent variant, enabling better genetic counselling. Second, we also corrected for possible ascertainment bias by excluding all PDAC index cases from the analysis, thereby avoiding risk overestimation. Third, it is unlikely that a recall or reporting bias substantially influenced our results. To minimise this risk, we excluded all untested second-degree and higher-degree family members (with and without PDAC) from the analyses. Furthermore, it has been shown that reported family histories have a near perfect (>99\%) negative predictive value for PDAC, ${ }^{38}$ and a high positive predictive value for PDAC diagnoses in first-degree relatives $(>75 \%){ }^{26}$

One limitation of our study should be noted. Notwithstanding the large number of families included, for each individual variant the number of families, variant carriers and PDAC cases was low. Besides the previously described p16-Leiden variant, the c.67G 
$>$ C, p.(Gly23Arg) variant was the only variant for which we had sufficient PDAC cases to calculate lifetime risk estimates. Clearly, achieving reliable future estimates of lifetime PDAC risk for most variants will require international reporting and the amalgamation of results on variant frequencies and PDAC occurrence.

In conclusion, a variety of pathogenic CDKN2A variants other than the relatively prevalent $\mathrm{p} 16$-Leiden variant are found in Dutch melanoma families. Pathogenic variants affecting p16INK4a (including c.67G >C, p.(Gly23Arg)), but not those affecting only p14ARF, appear to be associated with increased PDAC risk. Therefore, carriers of such variants should be eligible for pancreatic cancer surveillance programmes within a research setting.

\section{Author affiliations}

Department of Gastroenterology \& Hepatology, Erasmus University Medical Center, Rotterdam, The Netherlands

${ }^{2}$ Department of Biomedical Data Sciences, Leiden University Medical Center, Leiden, The Netherlands

${ }^{3}$ Department of Clinical Genetics, Erasmus University Medical Center, Erasmus MC

Cancer Institute, Rotterdam, The Netherlands

${ }^{4}$ Department of Clinical Genetics, Leiden University Medical Center, Leiden, The Netherlands

${ }^{5}$ Department of Genetics, University Medical Center Groningen, University of Groningen, Groningen, The Netherlands

${ }^{6}$ Family Cancer Clinic, The Netherlands Cancer Institute, Amsterdam, The Netherlands ${ }^{7}$ Department of Gastroenterology \& Hepatology, Leiden University Medical Center, Leiden, The Netherlands

\section{Acknowledgements The authors thank all participating clinical genetics departments for their contribution to the Dutch familial melanoma database and for updating the family pedigrees.}

Contributors The study was initiated and designed by KAO, AW and TPP. Variant analysis and interpretation was performed by NvdS. Clinical pedigree information was collected by KAO, AW, PCvdA, JCO, TvO, LEvdK and TPP. Statistical data analysis was performed by MR-G and the results were interpreted by KAO, MR-G, DLC, MJB and TPP. The manuscript was drafted by KAO and TPP, and critically reviewed by HFAV, FH, DLC and MJB. All authors approved the final manuscript.

Funding TPP is supported by a grant from the Dutch Cancer Society (\#UL 20157511).

Competing interests DLC is a consultant to Tramedico. MJB received research funding from Boston Scientific, Cook Medical, and Pentax Medical. He is a consultant to Boston Scientific, Cook Medical, Pentax Medical and Mylan. The other authors have no potential competing interests to disclose.

\section{Patient consent for publication Not required.}

Ethics approval The creation of the Dutch national database for familial melanoma received ethical approval from the institutional review board of the Leiden University Medical Center (\#C14.064).

Provenance and peer review Not commissioned; externally peer reviewed. Data availability statement Study data are available upon reasonable request.

Open access This is an open access article distributed in accordance with the Creative Commons Attribution 4.0 Unported (CC BY 4.0) license, which permits others to copy, redistribute, remix, transform and build upon this work for any purpose, provided the original work is properly cited, a link to the licence is given, and indication of whether changes were made. See: https://creativecommons.org/ licenses/by/4.0/

\section{ORCID iD}

Kasper A Overbeek http://orcid.org/0000-0003-1829-9963

\section{REFERENCES}

1 Aoude LG, Wadt KAW, Pritchard AL, Hayward NK. Genetics of familial melanoma: 20 years after CDKN2A. Pigment Cell Melanoma Res 2015;28:148-60.

2 Sherr CJ. The INK4a/ARF network in tumour suppression. Nat Rev Mol Cell Biol 2001;2:731-7.

3 Bishop DT, Demenais F, Goldstein AM, Bergman W, Bishop JN, Bressac-de Paillerets B, Chompret A, Ghiorzo P, Gruis N, Hansson J, Harland M, Hayward N, Holland EA, Mann GJ, Mantelli M, Nancarrow D, Platz A, Tucker MA, Melanoma Genetics C, Melanoma Genetics Consortium. Geographical variation in the penetrance of CDKN2A mutations for melanoma. J Natl Cancer Inst 2002;94:894-903.
4 Read J, Wadt KAW, Hayward NK. Melanoma genetics. J Med Genet 2016;53:1-14.

5 Tucker MA, Elder DE, Curry M, Fraser MC, Pichler V, Zametkin D, Yang XR, Goldstein AM. Risks of melanoma and other cancers in melanoma-prone families over 4 decades.J Invest Dermatol 2018:138:1620-6.

6 Goldstein AM. Familial melanoma, pancreatic cancer and germline CDKN2A mutations. Hum Mutat 2004;23:630.

7 Goldstein AM, Chan M, Harland M, Gillanders EM, Hayward NK, Avril M-F, Azizi E, Bianchi-Scarra G, Bishop DT, Bressac-de Paillerets B, Bruno W, Calista D, Cannon Albright LA, Demenais F, Elder DE, Ghiorzo P, Gruis NA, Hansson J, Hogg D, Holland EA, Kanetsky PA, Kefford RF, Landi MT, Lang J, Leachman SA, MacKie RM, Magnusson V, Mann GJ, Niendorf K, Newton Bishop J, Palmer JM, Puig S, Puig-Butille JA, de Snoo FA, Stark M, Tsao H, Tucker MA, Whitaker L, Yakobson E, the Melanoma Genetics Consortium (GenoMEL) 26. High-risk melanoma susceptibility genes and pancreatic cancer, neural system tumors, and uveal melanoma across GenoMEL. Cancer Res 2006:66:9818-28.

8 de Snoo FA, Bishop DT, Bergman W, van Leeuwen I, van der Drift C, van Nieuwpoort FA, Out-Luiting CJ, Vasen HF, ter Huurne JAC, Frants RR, Willemze R, Breuning $\mathrm{MH}$, Gruis NA. Increased risk of cancer other than melanoma in CDKN2A founder mutation (p16-Leiden)-positive melanoma families. Clin Cancer Res 2008:14:7151-7.

9 Goldstein AM, Fraser MC, Struewing JP, Hussussian CJ, Ranade K, Zametkin DP, Fontaine LS, Organic SM, Dracopoli NC, Clark WH. Increased risk of pancreatic cancer in melanoma-prone kindreds with p16INK4 mutations. N Eng/ J Med 1995;333:970-5

10 Vasen HF, Gruis NA, Frants RR, van Der Velden PA, Hille ET, Bergman W. Risk of developing pancreatic cancer in families with familial atypical multiple mole melanoma associated with a specific 19 deletion of p16 (p16-Leiden). Int J Cancer 2000;87:809-11.

11 Vasen H, Ibrahim I, Ponce CG, Slater EP, Matthäi E, Carrato A, Earl J, Robbers K, van Mil AM, Potjer T, Bonsing BA, de Vos Tot Nederveen Cappel WH, Bergman W, Wasser M, Klöppel G, Klöppel G, Schicker C, Steinkamp M, Figiel J, Esposito I, Mocci E, Vazquez-Sequeiros E, Muñoz-Beltran M, Muñoz-Beltran M, Montans J, Langer $P$, Fendrich V, Bartsch DK. Benefit of surveillance for pancreatic cancer in high-risk individuals: outcome of long-term prospective follow-up studies from three European expert centers. J Clin Oncol 2016;34:2010-9.

12 Hu C, Hart SN, Polley EC, Gnanaolivu R, Shimelis H, Lee KY, Lilyquist J, Na J, Moore R, Antwi SO, Bamlet WR, Chaffee KG, DiCarlo J, Wu Z, Samara R, Kasi PM, McWilliams RR, Petersen GM, Couch FJ. Association between inherited germline mutations in cancer predisposition genes and risk of pancreatic cancer. JAMA 2018:319:2401-9.

13 Overbeek KA, Cahen DL, Canto MI, Bruno MJ. Surveillance for neoplasia in the pancreas. Best Pract Res Clin Gastroenterol 2016:30:971-86.

14 Ghiorzo P, Fornarini G, Sciallero S, Battistuzzi L, Belli F, Bernard L, Bonelli L, Borgonovo G, Bruno W, De Cian F, Decensi A, Filauro M, Faravelli F, Gozza A, Gargiulo S, Mariette F, Nasti S, Pastorino L, Queirolo P, Savarino V, Varesco L, Scarrà GB, Genoa Pancreatic Cancer Study Group. CDKN2A is the main susceptibility gene in Italian pancreatic cancer families. J Med Genet 2012:49:164-70.

15 Zhen DB, Rabe KG, Gallinger S, Syngal S, Schwartz AG, Goggins MG, Hruban RH, Cote ML, McWilliams RR, Roberts NJ, Cannon-Albright LA, Li D, Moyes K, Wenstrup RJ, Hartman A-R, Seminara D, Klein AP, Petersen GM. BRCA1, BRCA2, PALB2, and CDKN2A mutations in familial pancreatic cancer: a PACGENE study. Genet Med 2015; 17:569-77

16 Harinck F, Kluijt I, van der Stoep N, Oldenburg RA, Wagner A, Aalfs CM, Sijmons RH Poley J-W, Kuipers EJ, Fockens P, van Os TAM, Bruno MJ. Indication for CDKN2Amutation analysis in familial pancreatic cancer families without melanomas. J Med Genet 2012:49:362-5.

17 Goggins M, Overbeek KA, Brand R, Syngal S, Del Chiaro M, Bartsch DK, Bassi C Carrato A, Farrell J, Fishman EK, Fockens P, Gress TM, van Hooft JE, Hruban RH, Kastrinos F, Klein A, Lennon AM, Lucas A, Park W, Rustgi A, Simeone D, Stoffel E, Vasen HFA, Cahen DL, Canto Ml, Bruno M, International Cancer of the Pancreas Screening (CAPS) consortium. Management of patients with increased risk for familial pancreatic cancer: updated recommendations from the International cancer of the pancreas screening (CAPS) Consortium. Gut 2020;69:7-17.

18 Goldstein AM, Struewing JP, Chidambaram A, Fraser MC, Tucker MA. Genotypephenotype relationships in U.S. melanoma-prone families with CDKN2A and CDK4 mutations. J Natl Cancer Inst 2000;92:1006-10.

19 Zhan W, Shelton CA, Greer PJ, Brand RE, Whitcomb DC. Germline variants and risk for pancreatic cancer: a systematic review and emerging concepts. Pancreas 2018:47:924-36.

20 Gruis NA, van der Velden PA, Sandkuijl LA, Prins DE, Weaver-Feldhaus J, Kamb A, Bergman W, Frants RR. Homozygotes for CDKN2 (p16) germline mutation in Dutch familial melanoma kindreds. Nat Genet 1995;10:351-3.

21 Goldstein AM, Chan M, Harland M, Gillanders EM, Hayward NK, Avril M-F, Azizi E, Bianchi-Scarra G, Bishop DT, Bressac-de Paillerets B, Bruno W, Calista D, Cannon Albright LA, Demenais F, Elder DE, Ghiorzo P, Gruis NA, Hansson J, Hogg D, Holland EA, Kanetsky PA, Kefford RF, Landi MT, Lang J, Leachman SA, Mackie RM, Magnusson V, Mann GJ, Niendorf K, Newton Bishop J, Palmer JM, Puig S, Puig-Butille JA, de Snoo FA, Stark M, Tsao H, Tucker MA, Whitaker L, Yakobson E, Melanoma Genetics C, Melanoma Genetics Consortium (GenoMEL). High-risk melanoma susceptibility genes 
and pancreatic cancer, neural system tumors, and uveal melanoma across GenoMEL. Cancer Res 2006:66:9818-28.

22 Potjer TP, Helgadottir H, Leenheer M, van der Stoep N, Gruis NA, Hoiom V, Olsson H, van Doorn R, Vasen HFA, van Asperen CJ, Dekkers OM, Hes FJ. Dutch Working group for clinical O. CM-Score: a validated scoring system to predict CDKN2A germline mutations in melanoma families from northern Europe. J Med Genet 2018;55:661-8.

23 Plon SE, Eccles DM, Easton D, Foulkes WD, Genuardi M, Greenblatt MS, Hogervorst FBL, Hoogerbrugge N, Spurdle AB, Tavtigian SV, IARC Unclassified Genetic Variants Working Group. Sequence variant classification and reporting: recommendations for improving the interpretation of cancer susceptibility genetic test results. Hum Mutat 2008:29:1282-91

24 Pollock PM, Spurr N, Bishop T, Newton-Bishop J, Gruis N, van der Velden PA, Goldstein AM, Tucker MA, Foulkes WD, Barnhill R, Haber D, Fountain J, Hayward NK. Haplotype analysis of two recurrent CDKN2A mutations in 10 melanoma families: evidence for common founders and independent mutations. Hum Mutat 1998;11:424-31.

25 Yakobson E, Eisenberg S, Isacson R, Halle D, Levy-Lahad E, Catane R, Safro M, Sobolev V, Huot T, Peters G, Ruiz A, Malvehy J, Puig S, Chompret A, Avril M-F, Shafir R, Peretz $\mathrm{H}$, Bressac-de Paillerets B. A single Mediterranean, possibly Jewish, origin for the Val59Gly CDKN2A mutation in four melanoma-prone families. Eur J Hum Genet 2003;11:288-96.

26 Fiederling J, Shams AZ, Haug U. Validity of self-reported family history of cancer: a systematic literature review on selected cancers. Int I Cancer 2016;139:1449-60.

27 Dutch Cancer Registration (NKR) I. [Web Page]. Netherlands Comprehensive Cancer Organisation [cited 18 November 2019], 2018. Available: www.cijfersoverkanker.nl

28 Kannengiesser C, Brookes S, del Arroyo AG, Pham D, Bombled J, Barrois M, Mauffret O, Avril M-FM, Chompret A, Lenoir GM, Sarasin A, Peters G, Bressac-de Paillerets $B$, French Hereditary Melanoma Study Group. Functional, structural, and genetic evaluation of 20 CDKN2A germ line mutations identified in melanoma-prone families or patients. Hum Mutat 2009;30:564-74.

29 Bruno W, Pastorino L, Ghiorzo P, Andreotti V, Martinuzzi C, Menin C, Elefanti L, Stagni C, Vecchiato A, Rodolfo M, Maurichi A, Manoukian S, De Giorgi V, Savarese I, Gensini F, Borgognoni L, Testori A, Spadola G, Mandalà M, Imberti G, Savoia P, Astrua C, Ronco AM, Farnetti A, Tibiletti MG, Lombardo M, Palmieri G, Ayala F, Ascierto P, Ghigliotti G, Muggianu M, Spagnolo F, Picasso V, Tanda ET, Queirolo P, BianchiScarrà G. Multiple primary melanomas (MPMs) and criteria for genetic assessment: MultiMEL, a multicenter study of the Italian melanoma intergroup. J Am Acad Dermatol 2016;74:325-32.
30 Berwick M, Orlow I, Hummer AJ, Armstrong BK, Kricker A, Marrett LD, Millikan RC, Gruber SB, Anton-Culver H, Zanetti R, Gallagher RP, Dwyer T, Rebbeck TR, Kanetsky PA, Busam K, From L, Mujumdar U, Wilcox H, Begg CB, GEM Study Group. The prevalence of CDKN2A germ-line mutations and relative risk for cutaneous malignant melanoma: an international population-based study. Cancer Epidemiol Biomarkers Prev 2006:15:1520-5.

31 Soufir N, Avril MF, Chompret A, Demenais F, Bombled J, Spatz A, Stoppa-Lyonnet D, Bénard J, Bressac-de Paillerets B. Prevalence of p16 and CDK4 germline mutations in 48 melanoma-prone families in France. The French familial melanoma Study Group. Hum Mol Genet 1998:7:209-16.

32 Fargnoli MC, Chimenti S, Keller G, Soyer HP, Dal Pozzo V, Höfler H, Peris K. CDKN2a/ p16INK4a mutations and lack of p19ARF involvement in familial melanoma kindreds. J Invest Dermatol 1998:111:1202-6.

33 Blackwood MA, Holmes R, Synnestvedt M, Young M, George C, Yang H, Elder DE, Schuchter LM, Guerry D, Ganguly A. Multiple primary melanoma revisited. Cancer 2002;94:2248-55.

34 Gensini F, Sestini R, Piazzini M, Vignoli M, Chiarugi A, Brandani P, Ghiorzo P, Salvini C, Borgognoni L, Palli D, Bianchi-Scarrà G, Carli P, Genuardi M. The p.G23S CDKN2A founder mutation in high-risk melanoma families from central Italy. Melanoma Res 2007; 17:387-92.

35 Scaini MC, Rossi E, de Siqueira Torres PLA, Zullato D, Callegaro M, Casella C, Quaggio M, Agata S, Malacrida S, Chiarion-Sileni V, Vecchiato A, Alaibac M, Montagna M, Mann GJ, Menin C, D'Andrea E. Functional impairment of p16(INK4A) due to CDKN2A p.Gly23Asp missense mutation. Mutat Res 2009;671:26-32.

36 Gerdes B, Bartsch DK, Ramaswamy A, Kersting M, Wild A, Schuermann M, Frey $M$, Rothmund M. Multiple primary tumors as an indicator for p16INK4a germline mutations in pancreatic cancer patients? Pancreas 2000;21:369-75.

37 Goldstein AM, Chan M, Harland M, Hayward NK, Demenais F, Bishop DT, Azizi E, Bergman W, Bianchi-Scarra G, Bruno W, Calista D, Albright LAC, Chaudru V, Chompret A, Cuellar F, Elder DE, Ghiorzo P, Gillanders EM, Gruis NA, Hansson J, Hogg D, Holland EA, Kanetsky PA, Kefford RF, Landi MT, Lang J, Leachman SA, MacKie RM, Magnusson V, Mann GJ, Bishop JN, Palmer JM, Puig S, Puig-Butille JA, Stark M, Tsao H, Tucker MA, Whitaker L, Yakobson E, Lund Melanoma Study Group, Melanoma Genetics Consortium (GenoMEL). Features associated with germline CDKN2A mutations: a GenoMEL study of melanoma-prone families from three continents. J Med Genet 2007:44:99-106.

38 Ziogas A, Anton-Culver H. Validation of family history data in cancer family registries. Am J Prev Med 2003;24:190-8. 